\title{
SZEMMOZGÁSOK ELEMZÉSE TRADICIONÁLIS ÉS ÚJSZERÚ VIZUÁLIS TESZTKÖRNYEZETBEN: A HÁTTÉRKÉP DISZTRAKTOR HATÁSA A SZAKKÁDIKUS PARAMÉTEREKRE
}

\section{SOMOSKEÖY SZABOLCS ${ }^{1 *}$ - KOVÁCS ILDIKÓ ${ }^{2 *}$ - MEZEI MÁRTON ${ }^{1}-$ HOFFMANN ILDIKÓ ${ }^{3}$ - TÓTH LÁSZLÓ ${ }^{4}$ - GOSZTOLYA GÁBOR ${ }^{4}$ - IMRE NÓRA ${ }^{2}$ - BALOGH RÉKA ${ }^{2}$ - PÁKÁSKI MAGDOLNA ${ }^{2}$ - KÁLMÁN JÁNOS ${ }^{2}$ - FEHÉR ANDRÁS ${ }^{1}$}

\author{
${ }^{1}$ iCollWare Kft. \\ ${ }^{2}$ Szegedi Tudományegyetem KK Pszichiátriai Klinika \\ ${ }^{3}$ Szegedi Tudományegyetem BTK Magyar Nyelvi és Irodalmi Intézet \\ Magyar Nyelvészeti Tanszék \\ ${ }^{4}$ Szegedi Tudományegyetem TTIK Informatikai Intézet \\ * egyenlố arányban járultak hozzá a kézirathoz \\ E-mail: szabolcs.somoskeoy@icollware.com
}

Benyújtva: 2020. február 5. - Elfogadva: 2020. augusztus 5.

\begin{abstract}
Háttér és célkitûzések: A szakkádikus szemmozgási paraméterek biomarkerként történö önálló használata egyes degeneratív neuropszhichiátriai kórképek felismerésében egyelöre kérdéses. Jelen vizsgálatunk célkitúzése egy olyan szakkádikus szemmozgásvizsgálati protokoll megvalósitása, amely a nemzetközi klinikai kutatásoknak megfelelöen kialakitott vizsgálati paraméterekkel jellemezhetô. Továbbá egészséges vizsgált személyek szakkádparamétereinek a nemzetközileg publikált adatokkal való összehasonlítása, illetve a Boston Sütilopás feladatban használt kép vizuális tesztkörnyezetbe történö beépitésének disztraktor-hatásvizsgálata a szakkádikus paraméterekre.

Módszer: Vizsgálatainkat egészséges önkéntes alanyokon végeztük Tobii Pro X3-120 berendezéssel, két eltérô vizuális környezetet tartalmazó, egyéb tekintetben teljesen megegyezö felépitésú, proszakkád és antiszakkád tesztek gap és overlap feladataiban. Az egyik csoport vizuális tesztkörnyezete standard szürke háttérböl és fekete stimulusokból állt (STD tesztcsoport), a másiké a Boston Afázia Teszt Sütilopás képleirási feladatban használt képet és zöld-piros színú stimulusokat tartalmazott (BSL tesztcsoport).

Eredmények: A proszakkád és antiszakkád overlap latencia mindkét csoportban nagyobb volt, mint a gap feladatban. A vizsgálati alanyok életkora közepes erôsségú módon korrelált az STD csoport proszakkád gap latenciájával, illetve a BSL csoport proszakkád overlap latencia, antiszakkád gap/overlap latencia és overlap idôtartam értékével. A csoportok közötti életkori eltérés statisztikai kontrollja mellett nem találtunk különbséget a proszakkád és antiszakkád latencia, illetve csúcssebesség tekintetében. A szakkád idôtartamok szignifikánsan rövidebbek voltak a BSL csoportban. Az iránytévesztési ráta a proszakkád tesztben megegyezett; az antiszakkád gap idôtartam, az overlap idôtartam, illetve a gap iránytévesztési ráta szignifikáns csoportkülönbséget mutatott.

Következtetések: A nemzetközi sztenderdeknek megfelelö újszerú vizsgálati protokoll alkalmasnak látszik hagyományos neuropszichológiai tesztekkel és kutatócsoportunk közelmúltban kidolgozott automatikus beszédfelismerô algoritmusokat alkalmazó tesztjeivel kombinálva egészséges és demencia szindrómával élố személyek multimodális klinikai vizsgálatában történö felhasználásra.
\end{abstract}

Kulcsszavak: szakkádikus szemmozgások, reflexív szakkád, antiszakkád, Boston Sütilopás kép, disztraktor 


\section{BEVEZETÉS}

A szakkád mindkét szem ugrásszerú, egyidejú gyors tandem mozgása, amely a tekintet egyik tárgyról a másikra történô fixációja közben, a két fixációs pont közötti elmozdulással megegyezô irányban lép fel. A szakkád a vizuális keresés, pásztázás egyik jellegzetes eszköze. A szemek szakkádikus mozgása közben eddigi ismereteink alapján nem történik információfelvétel (Antoniades és mtsai, 2013). A szakkádikus szemmozgások a központi idegrendszer kontrollja alatt álló alapvetô jelenségek, amelyek zavara a komplex központi idegrendszeri vezérlés valamilyen szintû érintettségére vezethetô vissza. Emiatt elemzésük számos neuropszichiátriai betegségben, pl. demencia szindrómák esetében, a klinikai kutatások középpontjában áll. Az utóbbi évek technikai fejlődésének köszönhetôen mára széles körben elérhetôvé váltak a noninvazív, magas mintavételi jelfrekvenciájú, szemmozgáskövetô kamerákra és a hozzájuk kapcsolt szemmozgásrögzítô és -elemzô számítógépes alkalmazásokra alapuló megoldások. Ennek köszönhetôen ugrásszerúen bóvült a szakkádikus szemmozgások központi idegrendszeri szabályozásával és klinikai állapotokban játszott szerepével kapcsolatos információk mennyisége (Antoniades és mtsai, 2013).

A szakkádikus szemmozgások klasszifikáció szempontjából négyféle kategóriába sorolhatók: vizuálisan vezérelt szakkádok, antiszakkádok, memóriavezérelt, illetve prediktív szakkádok (Antoniades és mtsai, 2013; Leigh és Zee, 2006). A vizuális vezérlésú szakkádok során a szemmozgás egy vizuális inger irányában történik. A vizuális vezérlésû szakkádok jellemzőit (amplitúdó, latencia, csúcssebesség, idôtartam) gyakran használják viszonyítási alapként az egyéb kategóriájú szakkádok értékeléséhez is. Ebbe a kategóriába tartoznak a reflexív vagy más néven proszakkádok és a pásztázó szakkádok, amelyek között az alapvetô különbség, hogy míg az elóbbit külsô, a látótér perifériáján felbukkanó vagy eltûnố vizuális inger váltja ki, az utóbbit az egyén azon belsố törekvése, amely révén a vizuális környezetét méri fel. Az antiszakkád a vizuális ingerrel ellentétes irányú szakkádikus szemmozgást jelent. Mivel a reflexív szakkád - elnevezésével ellentétben - akaratlagosan befolyásolható és elnyomható, a sikeres antiszakkád kivitelezése abból áll, hogy a periférikus vizuális ingerre adott proszakkád gátlása révén, akaratlagosan az ellentétes irányban indított szakkád kerül kivitelezésre (Hallett, 1978). A gátlás és az ezt követô kivitelezés okozza az antiszakkádokra jellemzô nagyobb latenciaértéket (Fischer és Weber, 1992; Coe és Munoz, 2017).

A memóriavezérelt szakkád egy emlékezetben lévô inger irányában történik vizuális stimulus nélkül. A prediktív szakkádok sorozata egy tekintettel fixált és követett mozgó célpont idôben és/vagy térben megjósolható elmozdulására irányul.

Az elmúlt évtizedekben kiemelt érdeklôdés övezte a szakkádparaméterek változását különbözô kórképekben. Számos közlemény számolt be a kognitív zavarral járó betegségekben reflexív szakkádok latenciaértékének növekedésérôl és az antiszakkád-hibaráta emelkedésérôl (Munoz és Everling, 2004; Peltsch, Hemraj, Garcia és Munoz, 2014; Yang, Wang, Su, Xiao és Kapoula, 2013). Ezzel ellentétben, kimondottan kevés, specifikusan egy-egy betegségre jellemzô, biomarkerként használható anomáliát írtak le, amely segítségével egyértelmúen azonosítani lehet a szóban forgó betegséget (Warr és Walker, 2012; Javaid, Brenton, Guo és Cordeiro, 2016). A vizuális vezérlésú refle- 
xív szakkádok és antiszakkádok kórképspecifikus elemzése elősegítheti a differenciáldiagnózist a hagyományos kognitív pszichológiai tesztek és egyéb klinikai vizsgálatok alkalmazása mellett. Továbbá a neurolingvisztikában és a nyelvpatológiában gyakran használatosak képleírási feladatok, amelyek a diskurzusban bekövetkezô olyan változások feltérképezésére és követésére hivatottak, melyek afázia vagy demencia hatására jelennek meg. Ezen képleírások közül a kutatásban a legnépszerúbb a Boston Afázia Teszt Cookie Theft (Sütilopás) feladata (Goodglass és Kaplan, 1983; Giles, Patterson, és Hodges, 1996; Forbes-McKay és Venneri, 2005).

A kéziratban bemutatásra kerüló jelen vizsgálat egy olyan komplex klinikai kutatás elsô részét képezi, amelynek célja a szemmozgások, ill. egyes nyelvi paraméterek eltéréseinek potenciális biomarkerként történó vizsgálata demenciákban. Az elôtanulmányként szolgáló jelen vizsgálat a klinikai kutatáson belül alkalmazni tervezett, olyan szemmozgásvizsgálati protokoll létrehozását és egészséges önkénteseken történô validálását célozza, amely a nemzetközi irodalomban található ajánlásoknak megfelelô általános megfontolások szerint kerül kialakításra, és a klinikai kutatásokban leggyakrabban használt vizsgálati paraméterekkel jellemezhetô. Vizsgálatunk másik fontos célja volt, hogy a létrehozott szemmozgásvizsgálati protokollt egészséges önkéntes alanyokon, valós gyakorlati körülmények között teszteljük, és a proszakkádok és antiszakkádok így kapott paramétereinek értékeit a nemzetközileg publikált adatokkal összehasonlítsuk. Fix értékú szakkádamplitúdó mellett a szakkádparaméterek közül a latenciát, az idôtartamot, a csúcssebességet és az iránytévesztési rátát vizsgáltuk (Bahill, Clark és Stark, 1975).

A szakkádikus szemmozgásvizsgálatokban elterjedten alkalmazott, egyszerú szürke-fekete vizuális tesztkörnyezet mellett a kialakításra került vizsgálati protokollunk alternatív változatában a Boston Afázia Teszt Cookie Theft (Sütilopás) feladatában található vonalas rajzot a tesztkörnyezet háttérképeként alkalmaztuk, színes vizuális ingerekkel kiegészítve. Ennek elsôdleges oka és célja az volt, hogy a tervezett komplex klinikai vizsgálat részét képezô beszédelemzési tesztekben alkalmazott képleírási feladatokkal összeegyeztethetô vizuális környezetben is kerüljön kidolgozásra egy szemmozgásvizsgáló protokoll. Az alternatív szemmozgásvizsgáló tesztkörnyezetben a Boston Sütilopás kép adaptált verziójának használata mellett döntöttünk, hogy ezáltal vizsgálati eredményeink nemzetközi összehasonlíthatóságát biztosítsuk, és a szakterület standard vizsgálómódszeréhez is megfelelôen igazodjunk, valamint saját eddigi klinikai kutatásaink során alkalmazott, Boston Afázia Tesztre alapuló képleírási feladatok eredményeivel is kompatibilisek legyünk (Gosztolya és mtsai, 2019).

A kétféle vizuális környezetben végrehajtott szakkádikus szemmozgásvizsgálatok eredményeit egymással is összevetettük, és hipotézisünk az volt, hogy a jelentésteli disztraktor háttéringerrel ellátott tesztkörnyezet hatással lesz a szakkádparaméterekre pro- és antiszakkád feladatban is: ezen csoport nagyobb mértékú iránytévesztéssel, több szakkádhibával, nagyobb latenciával és csúcssebességgel jellemezhetô, mint a hagyományos szürke-fekete vizuális tesztkörnyezetben vizsgált csoport. 


\section{MÓDSZEREK}

\section{Vizsgálati minta}

A vizsgálatokat egészséges önkéntes alanyokon végeztük. A vizsgálati alanyokat két csoportban vizsgáltuk: az 1. számú csoport $(N=24) 10$ nô és 14 férfi tagból állt, akik életkora 35 és 62 év között változott $(M=45,00 ; S D=7,38 ; M d n=43,00$ év). A 2. számú csoport $(N=22) 50$ és 71 év között változó életkorú 7 noobool és 15 férfiból állt $(M=$ 60,$23 ; S D=6,98 ; M d n=60,50$ év). A csoportokba történô besorolásnál nem alkalmaztunk randomizálást.

A vizsgálatból történô kizárási indokot jelentett az önkéntes jelentkezôk anamnézisében szereplô agyvérzés, szembetegség, glaukóma, súlyos mértékú miópia ( $\mathrm{D}$ > 10,0; korrekcióval kezelt is), meglévó neurodegeneratív és pszichiátriai betegségek, a demenciák összes típusa, Alzheimer-kór és Parkinson-kór. Az összesen 50 jelentkezó közül 1-1 fő korábbi agyvérzés, nagyfokú miópia, illetve glaukóma miatt nem került beválogatásra. A fennmaradó egy fó teszteredménye az antiszakkád tesztben mutatott értékelési küszöbkritérium alatti teljesítmény miatt nem szerepelt az elemzésekben.

\section{Kutatásetikai és adatkezelési eljárásrend}

A vizsgálati alanyok a vizsgáló orvostól személyes szóbeli tájékoztatást kaptak a vizsgálati eljárásról, az elvégzendô tesztekrôl és a vizsgálat menetérôl. A jelentkezók a vizsgálatokba történô, írásbeli informált beleegyezésüket adták. A vizsgálati protokoll a Szegedi Tudományegyetem Szent-Györgyi Albert Klinikai Központ Humán Orvosbiológiai Intézményi és Regionális Kutatásetikai Bizottság jóváhagyásával került alkalmazásra (engedélyszám: 239/2017-SZTE).

A vizsgálat során az információs önrendelkezési jogról és az információszabadságról szóló 2011. évi CXII. törvény, az egészségügyi és a hozzájuk kapcsolódó személyes adatok kezelésérôl és védelmérôl szóló 1997. évi XLVII. törvény rendelkezéseit alkalmaztuk. A beteg adatainak kezelése megfelelt az Európai Parlament és a Tanács (EU) 2016/679 rendelete (GDPR) szabályainak. A vizsgálati eredmények nyilvántartása, tárolása és feldolgozása az illetô személyes adataitól mentesen, teljes anonimizálást követôen történt.

\section{Szemmozgásvizsgáló berendezés}

A vizsgálatokat Tobii Pro X3-120 berendezéssel (Tobii Pro, Tobii AB, Stockholm, Svédország), $120 \mathrm{~Hz}$ mintavételi frekvencia mellett végeztük, a gyártó ajánlásainak betartása mellett, 27" 1920 × 1080 képpont felbontású LCD-monitor használatával. A szemmozgások követésével és rögzítésével járó számítógép-múveleteket a gyártó által biztosított külsố adatfeldolgozó egység végezte (Tobii Pro External Processing Unit, Tobii Pro, Tobii AB, Stockholm, Svédország). A szemmozgások rögzítéséhez és a szakkádikus szemmozgások paramétereinek kinyeréséhez Tobii Pro Lab alkalmazást (Tobii Pro, Tobii 
AB, Stockhom, Svédország, verziószám: 1.123) használtunk. A szemmozgások mindkét szemes rögzítéséhez az alkalmazás alapértelmezett tekintéskövetési szúrőjét alkalmaztuk (Tobii Velocity-Threshold Identification [I-VT] Gaze Filter), annak alapértelmezett beállításai mellett: gap fill-in: off; szemválasztás: átlagos; zajszúrés: Moving Median; sebességkalkulátor: 20 ms idôablak; I-VT fixációs osztályozó: 30 ms határérték (Salvucci és Goldberg, 2000; Komogortsev, Gobert, Jayarathna, Koh és Gowda, 2010), fixációk közötti maximális idô: 75 ms; maximum eltérés: 0,5 fok; minimum fixáció: $60 \mathrm{~ms}$.

\section{Szemmozgásvizsgálati tesztek}

A vizsgálati alanyok a teszteket a Tobii Pro X3-120 kamerától 65 cm távolságban elhelyezett széken, kényelmes ülőhelyzetben, elsötétített vizsgálóhelyiségben végezték. A vizsgálatokat fejtámasz alkalmazása nélkül végeztük, az alanyok feje nem került rögzítésre. A pupillák sötétadaptációjához 3 perces idôtartamot biztosítottunk az alanyok számára a teszt megkezdése elôtt. Minden egyes teszt elsô lépéseként a vizsgálati alanyok a Tobii Pro Lab alkalmazás beépített 9 pontos kalibrációját hajtották végre, majd ezután, a szóbeli és a képernyőn látható instrukciókat követôen, egy feladatonként 5-5 lépésból álló gyakorlásra volt lehetôségük a teszt megkezdése elótt.

A szemmozgásokat két eltérô vizuális felépítésû tesztváltozatban vizsgáltuk. A két változat közötti alapvetô különbséget a tesztben használt háttérgrafika és a megjelenô vizuális ingerek színe jelentette. A centrális fixációs inger és a célingerek mérete, kitérítése, az ingerek idôzítése, a tesztfelépítés és a vizsgálatok egyéb paraméterei a két tesztben teljesen megegyezőek voltak. A két változat teljes vizuális tartalmát az 1. ábra mutatja be.
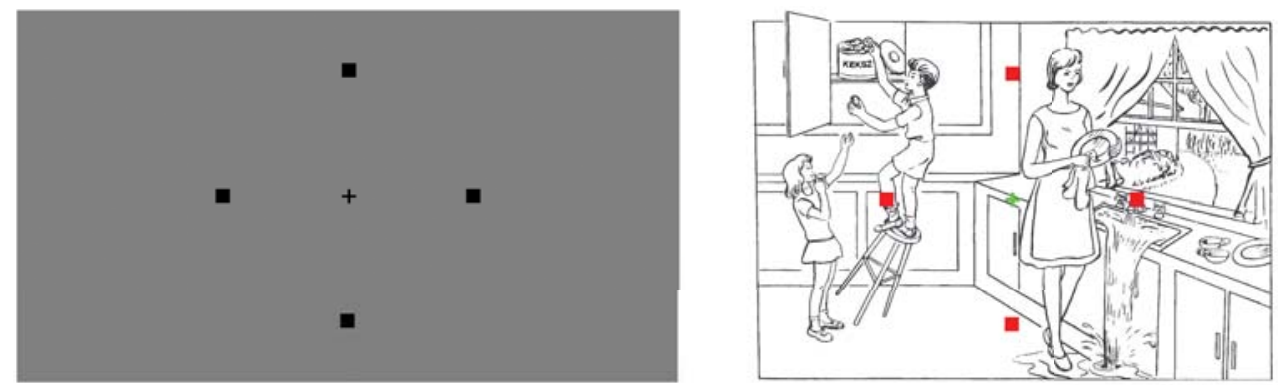

1. ábra. A Standard [STD] és Boston Sütilopás [BSL] hátteret alkalmazó teszt teljes vizuális tartalma

Megjegyzés: bal oldali kép - STD környezet: $1920 \times 1080$ képpont méretú, 50\%-os szürke árnyalatú homogén háttér, $1^{\circ}$ méret, fekete színú centrális fixációs kereszt és fekete színú célinger négyzetek $10^{\circ}$ eltérítéssel; jobb oldali kép - BSL környezet: $1920 \times 1080$ képpont méretú, fehér homogén háttéren fekete vonalas rajz digitálisan javított minôségú, magyar nyelvre adaptált („Cookie jar” = „Keksz”) változata, $1^{\circ}$ méretú, zöld színú centrális fixációs kereszt és piros színú célinger négyzetek $10^{\circ}$ eltérítéssel 
Az elsô, hagyományos tesztben a képernyô háttere homogén 50\%-os szürkeárnyalatú volt, megfelelố kontrasztot biztosítva a feladat végrehajtásához (Peltsch és mtsai, 2014). A tesztben alkalmazott centrális fixáció ingere a képernyó középpontjában megjelenô, $1^{\circ}$ méretû, fekete színú kereszt, a szakkádok kiváltásához használt ingerek ugyancsak $1^{\circ}$ méretû, fekete négyzetek voltak, amelyek a centrális fixációs kereszthez viszonyítva $10^{\circ}$-os periférikus eltérítésben, alatta, felette, jobbra vagy balra jelentek meg pszeudorandom sorrendben. Az STD típusú teszteket az 1. számú vizsgálati csoport végezte, amire emiatt STD csoportként hivatkozunk a szövegben.

\section{Boston Sütilopás teszt (BSL)}

Ebben a tesztben a képernyő hátterét a neurolingvisztikában és a nyelvpatológiában gyakran alkalmazott képleírási feladatok egyik legnépszerúbb változatában, a Boston Sütilopás (Boston Cookie Theft) feladatban (Goodglass és Kaplan, 1983) alkalmazott, fekete-fehér grafika $1920 \times 1080$ képpontos képernyôfelbontásra és magyar nyelvre adaptált, digitális verziója alkotta. A centrális fixáció ingere a kép középpontjában megjelenô $1^{\circ}$ méretû, zöld színú kereszt, a szakkádok kiváltásához használt ingerek ugyancsak $1^{\circ}$ méretû, piros négyzetek voltak, amelyek a centrális fixációs kereszthez viszonyítva $10^{\circ}$ eltérítésben, alatta, felette, jobbra vagy balra jelentek meg pszeudorandom sorrendben. A BSL típusú teszteket a 2. számú vizsgálati csoport végezte, amelyre a továbbiakban BSL csoportként hivatkozunk a szövegben.

\section{Gap és overlap típusú feladatok}

Vizsgálatainkban a szakkádikus szemmozgásvizsgálatokban régóta elterjedten használt gap és overlap feladatokat egyaránt alkalmaztuk (Saslow, 1967). A két feladat felépítését a 2. ábra mutatja be.

A gap típusú feladat felépítése megegyezett a korábban megjelent közleményekben szereplô, egyik elterjedten alkalmazottal (Reuter-Lorenz, Hughes és Fendrich,

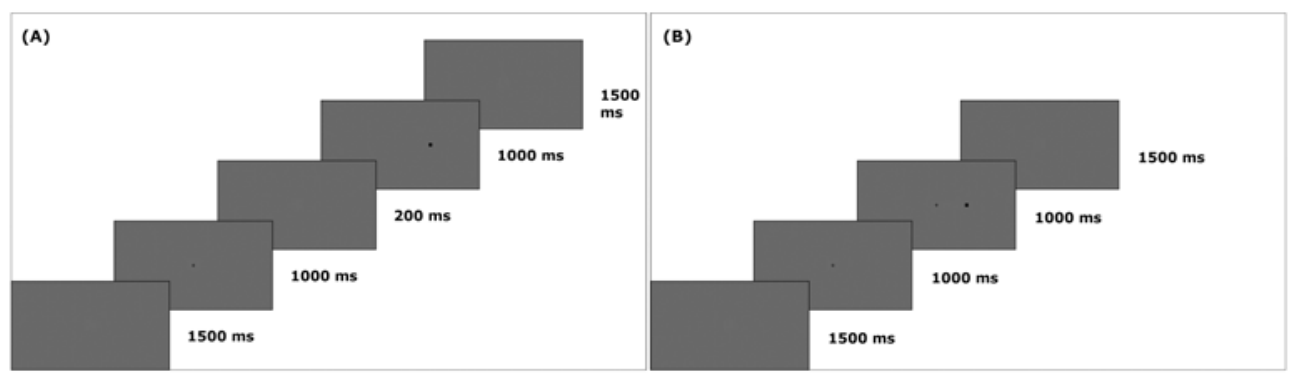

2. ábra. A tesztekben alkalmazott gap és overlap feladat szekvenciális felépítése

Megjegyzés: bal oldali kép -balról jobbra haladva, a gap feladat egy ciklusának sematikus sorrendje; jobb oldali kép - balról jobbra haladva, az overlap feladat egy ciklusának sematikus sorrendje 
1991). Egy feladatciklus a háttéren megjelenô, 1000 ms idôtartamig látható centrális fixációs ingerrel kezdôdött, majd 200 ms-ig csak a hátteret ábrázoló lépést követôen megjelenô, 1000 ms idôtartamig tartó szakkádikus célingerrel folytatódott, amelynek eltûnését egy 1500 ms idôtartamú újabb, csak hátteret ábrázoló lépés követte. Ezután az elôzô négy lépésbôl álló, új ciklus kezdôdött. Egy gap típusú feladatblokk 20 egyforma ciklusból épült fel.

Az overlap típusú feladatblokk szintén a háttéren megjelenô, 1000 ms idôtartamig látható centrális fixációs ingerrel kezdôdött, amelyet azonban a centrális fixációs inger eltûnése nélkül megjelenô, 1000 ms ideig látható szakkádikus stimulus követett. Tehát a szakkádikus stimulus a centrális fixációs ingerrel együttesen, idôbeli átfedésben volt látható, majd mindkettô eltûnését követôen, a ciklus 1500 ms hosszúságú, csak a hátteret ábrázoló lépéssel ért véget. Ezután az előzô három lépésbôl álló, új ciklus kezdôdött. Egy overlap típusú feladatblokk szintén 20 azonos felépítésú ciklusból állt.

\section{Proszakkádikus szemmozgásvizsgálatok}

A reflexív vagy más néven proszakkádok vizsgálatához alkalmazott gap és overlap típusú feladatokban a vizsgálati alanyoknak szóló utasítás abból állt, hogy a centrális fixációs ingerhez képest bármelyik irányban megjelenô stimulusra - annak megjelenését követốen - gyorsan pillantsanak rá, majd a stimulus eltûnését követôen újra a centrális fixációs jelre fókuszáljanak (Antoniades és mtsai, 2013).

A szakkádikus stimulus megjelenési idôpontjához viszonyítva csak a $80 \mathrm{~ms}$ alsó (Fischer és Weber, 1997) és 540 ms felsố határértékek (Klein, Raschke és Brandenbusch, 2003) közötti latenciát mutató szakkádokat fogadtuk el az ingerhez kapcsolódó, érvényes reflexív szakkádként. A proszakkád validitásának és a feladat iránytévesztési arányának meghatározásánál csak a stimulus pozíciójával megegyezô irányban, szimmetrikusan elhelyezkedô, 90 fokos körszelet határain belül detektált szakkádokat tartottuk helyes irányban kivitelezettnek, az 1. táblázat adatai és a 3. ábra példája szerint.

A ciklus alatt rögzítésre került, 100 \% s csúcssebességértéknél lassabb szakkádokat, függetlenül a latenciaidejük értékétôl és helyes irányuktól, nem vettük figyelembe reflexív szakkádként (Liu, Zhao, Ren, Wang és Zheng, 2018). Azon vizsgálati alany eredményei nem kerültek bele a végsố statisztikai elemzésekbe, aki feladatonként nem produkált minimum 10-10 érvényes (50\%) szakkádtípust.

1. táblázat. Helyes szakkádirány meghatározása a pro- és antiszakkád vizsgálatokban

\begin{tabular}{lcc}
\hline célinger pozíció & helyes proszakkád iránya & helyes antiszakkád iránya \\
\hline alul & $225-315^{\circ}$ & $45-135^{\circ}$ \\
felül & $45-135^{\circ}$ & $225-315^{\circ}$ \\
balra & $135-225^{\circ}$ & $315-360^{\circ}$ vagy $0-45^{\circ}$ \\
jobbra & $315-360^{\circ}$ vagy $0-45^{\circ}$ & $225-315^{\circ}$ \\
\hline
\end{tabular}

Megjegyzés: A célinger pozíciójától függôen kapott helyes szakkád iránya fokban megadva a centrális fixációs inger pozíciójából mint középpontból számított, fokban megadott határértékek között kell legyen. 

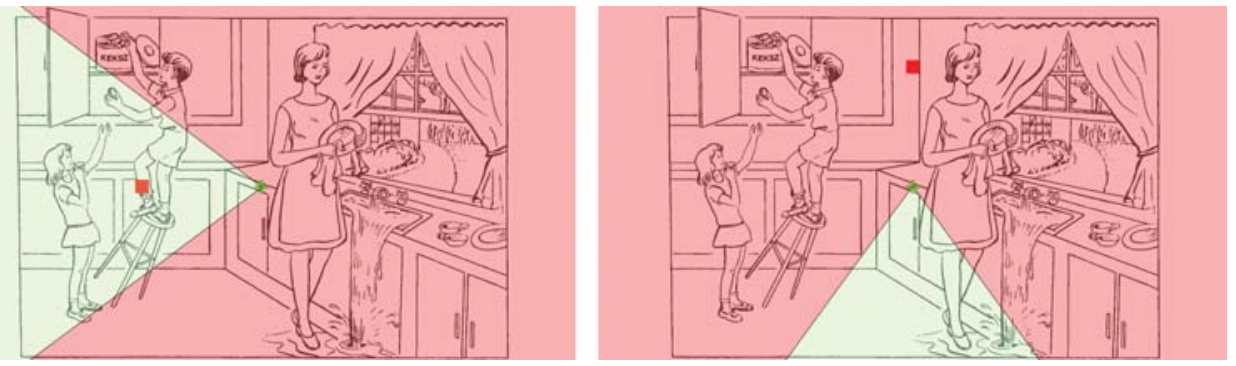

3. ábra. A Boston Sütilopás [BSL] képet háttérként alkalmazó tesztekben detektált helyes szakkádirány elbírálásának sematikus ábrázolása

Megjegyzés: bal oldali kép - proszakkád vizsgálati példa: bal oldali célinger esetén helyes irányúnak elfogadott szakkád a háromszögalakú területen belül található; jobb oldali kép - antiszakkád vizsgálati példa: felsố célinger esetén helyes irányúnak elfogadott szakkád a

háromszögalakú területen belülre esik

\section{Antiszakkádikus szemmozgásvizsgálatok}

Az antiszakkádok vizsgálatához alkalmazott gap és overlap típusú feladatokban a vizsgálati alanyoknak szóló utasítás abból állt, hogy a centrális fixációs ingerhez képest bármelyik irányban megjelenô stimulus pozíciójával ellentétes irányba tekintsenek az inger megjelenését követôen, majd a stimulus eltûnését követôen újra a centrális fixációs jelre fókuszáljanak (Antoniades és mtsai, 2013).

A szakkádikus stimulus megjelenéséhez viszonyított latencia $80 \mathrm{~ms}$ alsó és $540 \mathrm{~ms}$ felsố határértéke, a proszakkádokéhoz hasonlóan változatlan volt az ingerhez kapcsolódó érvényesség elbírálásában. Az antiszakkád validitásának és a feladat iránytévesztési arányának meghatározásánál csak a megjelenô stimulus pozíciójával ellentétes irányban elhelyezkedô 90 fokos körszelet határain belül detektált szakkádokat fogadtuk el helyes irányban kivitelezett antiszakkádként, szintén az 1. táblázat adatai és a 3. ábra példája szerint. A proszakkádok eseténél alkalmazott szabály itt is érvényes volt: a ciklus alatt rögzítésre került, 100 \% s csúcssebességértéknél lassabb szakkádokat, függetlenül a latenciaidejük értékétôl és helyes irányuktól, szintén nem vettük figyelembe. Azon vizsgálati alany eredményei szintén nem kerültek bele a végsố statisztikai elemzésekbe, aki feladatonként nem produkált minimum 10-10 érvényes (50\%) szakkádtípust.

\section{Ingerbemutatások elrendezése}

Minden vizsgálati alany esetében a vizsgálat egy proszakkádikus tesztből és egy azt követô antiszakkádikus tesztbôl állt. Mindkét teszt során a 20 ciklusból álló gap feladatot a szintén 20 ciklusos overlap feladat követte, szünet nélkül. A pro- és antiszakkádikus teszt között 1 perces szünet volt. A vizsgálati alanyok minden elvégzendô feladatsor eloott szóbeli és a képernyoón olvasható instrukciókat kaptak. A Boston Sütilopás tesztkörnyezetben a proszakkádikus teszt elindítása eloott minden vizsgálati alany részére 60 másodperces idôtartamot biztosítottunk a BSL háttérkép néma áttekintésére. 


\section{Adatfeldolgozás és statisztikai analizis}

A rögzített szemmozgásrekordok adatait a Tobii Pro Lab alkalmazás segítségével exportáltuk, és Microsoft Excel 2016 MSO (Microsoft Corporation, Redmond, Washington, Amerikai Egyesült Államok, verziószám: 16.0.12730.20144), illetve Microsoft Visual Basic (Microsoft Corporation, Redmond, Washington, Amerikai Egyesült Államok, verziószám: 7.1.1097) programmal dolgoztuk fel. A statisztikai elemzésekhez az adatok előfeldolgozása is Microsoft Excel alkalmazásban történt. A Tobii Pro Lab alkalmazás beépített gyári algoritmus segítségével automatikusan detektálja és jelöli a rögzített állományban előforduló szakkádokat. A rögzítésre került szemmozgásrekordok tartalmazzák az egyes jelölésre került szakkádok kezdetének és végének, valamint az alkalmazott stimulusoknak az idôbélyegzőjét, mely alapján a szakkád latenciája és idôtartama egyszerúen meghatározható. A szoftver által kiexportált Saccade Metrics állomány ezenfelül tartalmazza a kérdéses szakkád irányát és csúcssebességét. A szakkád irányának értéke alapján meghatározható volt a szakkádirány helyessége.

Meghatároztuk minden vizsgálati alany érvényes szakkádjaira vonatkozóan a latencia, idôtartam és csúcssebesség egyedi és egyénre jellemzó átlagértékét a gap és overlap feladatban, valamint a két vizsgálati csoportban (STD/BSL) kapott átlagértékeket. Ugyancsak meghatároztuk a helytelen irányban kivitelezett pro- és antiszakkádok arányát az összes érvényes szakkád százalékos arányában kifejezve (iránytévesztési ráta), egyénenként és csoportonként.

Az eredmények statisztikai elemzése JASP statisztikai elemzőszoftver segítségével történt (JASP Team, 2020, verziószám: 0.12.2, Windows 64-bit). Az STD/BSL tesztek gap/overlap és proszakkád/antiszakkád feladataiban kapott változók értékeinek normál eloszlását Shapiro-Wilk-teszt segítségével ellenôriztük. A mintáinkban található, nem normál eloszlást mutató szemmozgás-paraméterekre tekintettel a vizsgálati csoportokon belüli gap-overlap és proszakkád-antiszakkád paraméterek összehasonlításához Wilcoxon-féle elôjeles rangpróbát, az összes paraméter csoportok közötti öszszehasonlításához Mann-Whitney U-tesztet végeztünk. A szemmozgás-paraméterek vizsgálati csoportok közötti összehasonlítására az életkort mint kovariánst alkalmazó egyszempontos kovarianciaanalízist (ANCOVA) is kiviteleztünk. A szakkádikus paramétereknek az alanyok életkorával való összefüggését Kendall-féle rangkorrelációs vizsgálattal ítéltük meg. Az alkalmazott összes teszt statisztikai szabadságfoka egységes volt $(\alpha=0,05)$.

Az eredmények közlésében a leíró statisztikai paraméterek, és a normalitásvizsgálatot követôen a csoporton belüli gap és overlap eredmények bemutatása, ezt követôen a vizsgálati csoporton belüli szakkád és antiszakkád paraméterek összevetése, végül a csoportok közötti szakkádparaméter-különbségek ismertetése történik, tekintetbe véve a csoportok közötti életkori különbségek szerepét (és annak kontrollálását). 


\section{EREDMÉNYEK}

\section{Leíró statisztika és normalitásvizsgálat}

A vizsgálati csoportokban produkált proszakkád és antiszakkád paraméterek jellemzóinek összefoglalását a 2. táblázat tartalmazza.

2. táblázat. A vizsgálati csoportok proszakkád és antiszakkád paramétereinek leíró statisztikája és normalitásvizsgálata

Proszakkád paraméterek

\begin{tabular}{|c|c|c|c|c|c|c|c|c|c|}
\hline \multirow[b]{2}{*}{$\begin{array}{l}\text { STD csoport } \\
(N=24)\end{array}$} & \\
\hline & $M$ & $M d n$ & $S D$ & variancia & $\begin{array}{l}\text { ferde- } \\
\text { ség }\end{array}$ & $\begin{array}{l}\text { csúcsos- } \\
\text { ság }\end{array}$ & $W$ & $p$ & eloszlás \\
\hline életkor* (év) & 45 & 43,0 & 7,54 & 56,783 & 0,971 & 0,183 & 0,895 & 0,017 & $\begin{array}{c}\text { nem } \\
\text { normál }\end{array}$ \\
\hline nem*** (férfi, nö) & 1,417 & 1,000 & 0,504 & 0,254 & 0,361 & $-2,048$ & 0,629 & $<0,001$ & $\begin{array}{c}\text { nem } \\
\text { normál }\end{array}$ \\
\hline gap latencia (ms) & 153,27 & 147,83 & 26,69 & 712,568 & 0,58 & $-0,507$ & 0,946 & 0,220 & normál \\
\hline $\begin{array}{l}\text { overlap latencia } \\
(m s)\end{array}$ & 186,39 & 182,93 & 28,05 & 786,689 & 0,281 & $-0,315$ & 0,962 & 0,476 & normál \\
\hline gap idôtartam (ms) & 46,67 & 47,07 & 6,10 & 37,255 & $-0,126$ & $-0,437$ & 0,959 & 0,409 & normál \\
\hline $\begin{array}{l}\text { overlap idôtartam } \\
\text { (ms) }\end{array}$ & 46,53 & 46,37 & 6,96 & 48,467 & $-0,021$ & $-1,097$ & 0,958 & 0,393 & normál \\
\hline $\begin{array}{l}\text { gap csúcssebesség } \\
(\% / s)\end{array}$ & 342,74 & 346,56 & 42,58 & $\begin{array}{c}1 \\
813,365\end{array}$ & $-0,39$ & $-0,7$ & 0,955 & 0,401 & normál \\
\hline $\begin{array}{l}\text { overlap csúcssebes- } \\
\text { ség }(\% / s)\end{array}$ & 330,82 & 337,43 & 39,51 & $\begin{array}{c}1 \\
561,371 \\
\end{array}$ & $-0,346$ & $-0,611$ & 0,945 & 0,205 & normál \\
\hline $\begin{array}{l}\text { gap iránytévesztési } \\
\text { ráta*** }(\%)\end{array}$ & 8,61 & 6,28 & 12,28 & 150,753 & 2,034 & 4,672 & 0,728 & $<0,001$ & $\begin{array}{c}\text { nem } \\
\text { normál }\end{array}$ \\
\hline $\begin{array}{l}\text { overlap iránytévesz- } \\
\text { tési ráta*** }(\%)\end{array}$ & 6,06 & 0,00 & 7,90 & 62,407 & 1,101 & 0,181 & 0,773 & $<0,001$ & $\begin{array}{c}\text { nem } \\
\text { normál }\end{array}$ \\
\hline
\end{tabular}

\begin{tabular}{|c|c|c|c|c|c|c|c|c|c|}
\hline $\begin{array}{l}\text { BSL csoport }(N \\
=22)\end{array}$ & $M$ & $M d n$ & $S D$ & variancia & $\begin{array}{l}\text { ferde- } \\
\text { ség }\end{array}$ & $\begin{array}{l}\text { csúcsos- } \\
\text { ság }\end{array}$ & $W$ & $p$ & eloszlás \\
\hline életkor (év) & 60,23 & 60,5 & 6,98 & 48,755 & 0,257 & $-0,546$ & 0,956 & 0,416 & normál \\
\hline$n^{\prime} e^{* * *}(f e ́ r f i$, nö) & 1,273 & 1,000 & 0,456 & 0,208 & 1,097 & $-0,887$ & 0,562 & $<0,001$ & $\begin{array}{c}\text { nem } \\
\text { normál }\end{array}$ \\
\hline gap latencia (ms) & 159,43 & 153,85 & 27,33 & 746,853 & 0,347 & $-0,074$ & 0,980 & 0,913 & normál \\
\hline $\begin{array}{l}\text { overlap latencia } \\
(\mathrm{ms})\end{array}$ & 179,53 & 169,76 & 31,14 & 969,966 & 0,537 & $-0,362$ & 0,952 & 0,342 & normál \\
\hline gap idôtartam (ms) & 41,24 & 42,33 & 6,14 & 37,643 & 0,145 & $-0,749$ & 0,959 & 0,474 & normál \\
\hline $\begin{array}{l}\text { overlap idôtartam } \\
(\mathrm{ms})\end{array}$ & 39,15 & 38,27 & 7,73 & 59,75 & 0,116 & $-0,563$ & 0,958 & 0,440 & normál \\
\hline $\begin{array}{l}\text { gap csúcssebesség } \\
(\% / s)\end{array}$ & 320,44 & 319,51 & 29,12 & 848,11 & 0,079 & -0 , & 0,982 & 0,953 & normál \\
\hline $\begin{array}{l}\text { overlap csúcssebes- } \\
\text { ség }(\% / s)\end{array}$ & 316,50 & 313,46 & 25,32 & 641,218 & 0,936 & 1,72 & 0,948 & 0,462 & normál \\
\hline $\begin{array}{l}\text { gap iránytévesztési } \\
\text { ráta** }(\%)\end{array}$ & 6,94 & 6,67 & 7,86 & 61,737 & 0,761 & $-0,422$ & 0,833 & 0,002 & $\begin{array}{c}\text { nem } \\
\text { normál }\end{array}$ \\
\hline $\begin{array}{l}\text { overlap iránytévesz- } \\
\text { tési ráta*** }(\%)\end{array}$ & 7,96 & 0,00 & 10,59 & 112,075 & 1,536 & 2,745 & 0,764 & $<0,001$ & $\begin{array}{c}\text { nem } \\
\text { normál }\end{array}$ \\
\hline
\end{tabular}


Antiszakkád paraméterek

\begin{tabular}{|c|c|c|c|c|c|c|c|c|c|}
\hline $\begin{array}{l}\text { STD csoport }(N \\
=24)\end{array}$ & $M$ & $M d n$ & $S D$ & variancia & $\begin{array}{c}\text { ferde- } \\
\text { ség }\end{array}$ & $\begin{array}{l}\text { csúcsos- } \\
\text { ság }\end{array}$ & $W$ & $p$ & eloszlás \\
\hline gap latencia (ms) & 222,51 & 215,09 & 30,452 & 927,325 & 0,404 & $-0,652$ & 0,960 & 0,436 & normál \\
\hline $\begin{array}{l}\text { overlap latencia* } \\
(\mathrm{ms})\end{array}$ & 248,96 & 255,11 & 20,507 & 420,553 & $-0,999$ & 0,958 & 0,907 & 0,031 & $\begin{array}{c}\text { nem } \\
\text { normál }\end{array}$ \\
\hline gap idôtartam (ms) & 59,97 & 59,50 & 11,440 & 130,874 & 0,332 & $-0,440$ & 0,976 & 0,822 & normál \\
\hline $\begin{array}{l}\text { overlap idôtartam } \\
(\mathrm{ms})\end{array}$ & 57,81 & 58,05 & 9,876 & 97,538 & $-0,002$ & $-0,059$ & 0,976 & 0,803 & normál \\
\hline $\begin{array}{l}\text { gap csúcssebesség } \\
(\% / s)\end{array}$ & 288,84 & 285,14 & 48,451 & 2347,532 & $-0,059$ & 0,146 & 0,980 & 0,899 & normál \\
\hline $\begin{array}{l}\text { overlap csúcssebes- } \\
\operatorname{ség}(\% / s)\end{array}$ & 276,22 & 281,07 & 56,408 & 3181,890 & 0,001 & $-1,005$ & 0,960 & 0,443 & normál \\
\hline $\begin{array}{l}\text { gap iránytévesztési } \\
\text { ráta*** }(\%)\end{array}$ & 7,47 & 0,00 & 9,402 & 88,396 & 0,967 & $-0,075$ & 0,782 & $<0,001$ & $\begin{array}{c}\text { nem } \\
\text { normál }\end{array}$ \\
\hline $\begin{array}{l}\text { overlap iránytévesz- } \\
\text { tési ráta*** }(\%)\end{array}$ & 6,07 & 0,00 & 7,613 & 57,955 & 0,804 & $-0,895$ & 0,764 & $<0,001$ & $\begin{array}{c}\text { nem } \\
\text { normál }\end{array}$ \\
\hline
\end{tabular}

\begin{tabular}{|c|c|c|c|c|c|c|c|c|c|}
\hline $\begin{array}{l}\text { BSL csoport }(N \\
=22)\end{array}$ & $M$ & $M d n$ & $S D$ & variancia & $\begin{array}{l}\text { ferde- } \\
\text { ség }\end{array}$ & $\begin{array}{l}\text { csúcsos- } \\
\text { ság }\end{array}$ & $W$ & $p$ & eloszlás \\
\hline gap latencia (ms) & 223,81 & 230,31 & 66,082 & 4366,848 & $-0,081$ & $-0,883$ & 0,969 & 0,752 & normál \\
\hline $\begin{array}{l}\text { overlap latencia } \\
(\mathrm{ms})\end{array}$ & 240,13 & 260,65 & 64,366 & 4142,956 & $-0,369$ & $-1,159$ & 0,928 & 0,160 & normál \\
\hline gap idôtartam (ms) & 40,94 & 39,38 & 10,616 & 112,691 & 0,225 & $-0,815$ & 0,956 & 0,500 & normál \\
\hline $\begin{array}{l}\text { overlap idötartam } \\
(\mathrm{ms})\end{array}$ & 41,54 & 41,19 & 11,966 & 143,189 & 0,521 & 0,168 & 0,956 & 0,501 & normál \\
\hline $\begin{array}{l}\text { gap csúcssebesség } \\
(\% / \mathrm{s})\end{array}$ & 270,22 & 255,96 & 58,732 & 3449,459 & 0,311 & $-1,353$ & 0,922 & 0,157 & ormál \\
\hline $\begin{array}{l}\text { overlap csúcssebes- } \\
\text { ség }(\% / s)\end{array}$ & 268,44 & 269,85 & 42,828 & 1834,228 & $-0,213$ & 0,338 & 0,965 & 0,751 & normál \\
\hline $\begin{array}{l}\text { gap iránytévesztési } \\
\text { ráta* }(\%)\end{array}$ & 21,71 & 14,29 & 20,720 & 429,321 & 1,099 & 0,882 & 0,893 & 0,037 & $\begin{array}{c}\text { nem } \\
\text { normál }\end{array}$ \\
\hline $\begin{array}{l}\text { overlap iránytévesz- } \\
\text { tési ráta }\end{array}$ & 13,54 & 12,50 & 14,150 & 200,233 & 1,204 & 1,187 & 0,861 & 0,001 & $\begin{array}{c}\text { nem } \\
\text { normál }\end{array}$ \\
\hline
\end{tabular}

Megjegyzés: $M$ : átlag; $M d n$ : medián; $S D$ : szórás; $W$ : Shapiro-Wilk-teszt eredménye; $p$ : Shapiro-Wilk-teszt szignifikanciaértéke; $* p \leq 0,05 ; * * p \leq 0,01 ; * * * \leq 0,001$

A Shapiro-Wilk-teszt eredményei alapján megállapítható, hogy az STD csoportban nem normál eloszlást mutatott az életkor $[W(24)=0,895 ; p=0,017]$ és a nem $[W(24)$ $=0,629 ; p<0,001]$. A proszakkád paraméterek közül az STD csoportban a gap iránytévesztési ráta $[W(24)=0,7282 ; p \leq 0,001]$ és overlap iránytévesztési ráta $[W(24)=$ $0,773 ; p<0,001]$ mutatott nem normál eloszlást. A BSL csoportban szintén nem normál eloszlást követett a vizsgálati alanyok neme $[W(22)=0,562 ; p<0,001]$, valamint a gap iránytévesztési ráta $[W(22)=0,833 ; p=0,002]$ és az overlap iránytévesztési ráta $[W(22)=0,764 ; p<0,001]$. Az antiszakkád feladatok tekintetében az STD csoportban az overlap latencia $[W(24)=0,907 ; p=0,031]$, a gap iránytévesztési ráta $[W(24)$ $=0,782 ; p<0,001]$ és overlap iránytévesztési ráta $[W(24)=0,764 ; p<0,001]$ mutatott nem normál eloszlást. A BSL csoportban ugyancsak nem normál eloszlást követett az 
antiszakkád gap iránytévesztési ráta $[W(22)=0,893 ; p=0,037]$ és az overlap iránytévesztési ráta $[W(22)=0,861 ; p<0,001]$. A normalitásvizsgálat eredményei és a vizsgálati minták jellemzôi alapján a további statisztikai elemzések során nem paraméteres próbákat alkalmaztunk.

\section{Vizsgálati csoporton belüli gap és overlap eredmények összehasonlítása}

A proszakkád paraméterek tekintetében az elvégzett Wilcoxon-féle elójeles rangpróba eredményei alapján megállapítást nyert, hogy a saját vizsgálati csoporton belül mért proszakkád idôtartam-, csúcssebesség- és iránytévesztési ráta értékekben kimutatható gap/ overlap különbségek mértéke statisztikailag nem volt szignifikáns. Az STD csoportban a proszakkád latencia az overlap feladatban nagyobb volt $(M d n=182,93)$, mint a gap feladatban $(M d n=147,83)$, és a különbség statisztikailag szignifikáns mértékú volt $(Z=-5,295 ; p<0,001 ; r=0,872)$. Hasonlóképpen, a BSL csoportban a proszakkád latencia az overlap feladatban nagyobb volt $(M d n=169,76)$, mint a gap feladatban $(M d n=153,85)$, és a különbség statisztikailag szignifikáns mértékú volt $(Z=-3,063$; $p=0,002 ; r=0,623)$.

Az antiszakkád paraméterek esetében a Wilcoxon-féle elójeles rangpróba eredményei azt mutatták, hogy a saját vizsgálati csoporton belül mért antiszakkád idôtartam, csúcssebesség és iránytévesztési ráta értékekben a gap/overlap különbségek mértéke statisztikailag nem volt szignifikáns. Az STD csoportban az antiszakkád overlap latencia nagyobb volt $(M d n=255,11)$, mint a gap feladatban $(M d n=215,09)$, és a különbség statisztikailag szignifikáns mértékú volt $(Z=-3,586 ; p<0,001 ; r=0,732)$. A BSL csoportban az antiszakkád overlap latenciaértéke szintén nagyobb volt $(M d n=$ $260,65)$, mint a gap feladatban $(M d n=230,31)$, de a különbség nem ért el statisztikailag szignifikáns mértéket $(Z=-1,459 ; p=0,145 ; r=0,337)$.

\section{Vizsgálati csoporton belüli proszakkád és antiszakkád eredmények összehasonlítása}

Az ugyanazon vizsgálati tesztkörnyezetben kapott, vizsgálati csoporton belüli proszakkádikus paraméterértékek ugyanazon csoport antiszakkádikus paraméterértékekkel történô összehasonlítása Wilcoxon-féle elôjeles rangpróbával történt.

Az STD csoporton belül a kétféle szakkádikus szemmozgás latenciája, idôtartama és csúcssebessége a gap és overlap feladatban egyöntetúen különbözô volt, míg az iránytévesztési rátákban nem találtunk különbségeket.

A proszakkádikus gap és overlap latenciaértékek $(M d n=147,83$ és $M d n=182,93)$, valamint idôtartamértékek ( $M d n=47,07$ és $M d n=46,37)$ alacsonyabbak voltak, mint antiszakkádikus megfelelóik ( $M d n=215,09$ és $M d n=255,11$, valamint $M d n=59,50$ és $M d n=58,05)$, és ezek a különbségek szignifikáns mértékúek voltak $(Z=-5,295$; $p<0,001 ; r=0,872$; és $Z=-5,295 ; p<0,001 ; r=0,872$; valamint $Z=-3,586 ; p<0,001$; $r=0,732$; és $Z=-4,31 ; p<0,001 ; r=0,784)$. Ezzel egyidejúleg, a proszakkádikus gap és overlap csúcssebességek ( $M d n=346,56$ és $M d n=337,43)$ magasabb értékúek voltak az antiszakkádikus megfelelőjükhöz képest ( $M d n=291,29$ és $M d n=281,07)$, és a kü- 
lönbség szignifikáns mértékúnek bizonyult $(Z=3,478 ; p<0,001 ; r=0,692$; és $Z=4,358$; $p<0,001 ; r=0,79)$.

A BSL csoporton belül a kétféle szakkádikus szemmozgás gap és overlap feladatban mért latenciája és csúcssebessége egyaránt eltérô volt, míg az idôtartamokban nem mutattunk ki szignifikáns eltéréseket. Az iránytévesztési gyakoriságokban talált különbség a gap feladatban statisztikailag szignifikáns mértékúnek mutatkozott.

A proszakkádikus gap és overlap latenciaértékek ( $M d n=151,18$ és $M d n=169,76)$ alacsonyabbak voltak, mint antiszakkádikus megfelelôik $(M d n=228,80$ és $M d n=258,08)$, és a különbségek szignifikáns mértéküek voltak $(Z=-3,956 ; p<0,001 ; r=0,821$; és $Z=-3,592 ; p<0,001 ; r=0,77)$. A proszakkádikus gap és overlap csúcssebességértékek $(M d n=319,51$ és $M d n=314,99)$ magasabbak voltak, mint antiszakkádikus megfeleloóik ( $M d n=250,47$ és $M d n=266,01)$, és a különbségek szignifikáns mértékûek voltak $(Z=2,543 ; p=0,011 ; r=0,614$; és $Z=3,137 ; p=0,002 ; r=0,795)$. A gap feladatban detektált proszakkádikus iránytévesztési gyakoriság értéke $(M d n=6,67)$ alacsonyabb volt, mint az antiszakkádikus megfelelôje $(M d n=14,29)$, és a különbség szignifikáns mértékú volt $(Z=-2,202 ; p=0,028 ; r=0,534)$.

\section{Vizsgálati csoportok közötti különbségek a szakkádikus paraméterekben}

A proszakkád, illetve antiszakkád tesztekben a vizsgálati csoportok szerinti, MannWhitney U-próbával történô összehasonlítás eredményeit a 3. táblázat mutatja be.

A proszakkád paraméterek közül statisztikailag szignifikáns eltérés mutatkozott a gap időtartam $(U=140 ; p=0,007 ; r=0,400)$ és az overlap idôtartam $(U=123 ; p=0,002$; $r=0,456$ ) értékeiben. A proszakkád latencia, csúcssebesség, illetve az iránytévesztési ráta paraméterekben nem volt szignifikáns eltérés a csoportok mediánértékei között.

Az antiszakkád paraméterek közül statisztikailag szignifikáns eltérés volt a gap idôtartam $(U=50 ; p<0,001 ; r=0,662)$, az overlap idôtartam $(U=72 ; p<0,001 ; r=0,580)$, illetve a gap iránytévesztési ráta $(U=125,5 ; p=0,010 ; r=0,393)$ értékeiben. Az antiszakkád latencia, csúcssebesség, illetve az overlap iránytévesztési ráta paraméterekben nem találtunk szignifikáns eltérést a csoportok között.

3. táblázat. A vizsgálati csoportok közötti eltérések összehasonlító vizsgálatának eredményei

\begin{tabular}{|l|rcc|}
\multicolumn{1}{c|}{ Tesztalany jellemzök } & $\boldsymbol{U}$ & $\boldsymbol{r}$ & $\boldsymbol{p}$ \\
\cline { 2 - 4 } \multicolumn{1}{c|}{ Mann-Whitney U-próba } \\
\hline életkor*** & 41 & 0,722 & $<0,001$ \\
\hline nem & 302 & 0,144 & 0,318 \\
\hline
\end{tabular}

\begin{tabular}{|l|ccc|}
\cline { 2 - 4 } \multicolumn{1}{l|}{ Proszakkád paraméterek } & $\boldsymbol{U}$ & $\boldsymbol{r}$ & $\boldsymbol{p}$ \\
\hline gap latencia & 223 & 0,131 & 0,373 \\
overlap latencia & 224 & 0,128 & 0,385 \\
\hline gap idötartam** & 140 & 0,400 & 0,007 \\
overlap idôtartam** & 123 & 0,456 & 0,002 \\
\hline gap csúcssebesség & 142 & 0,301 & 0,051 \\
overlap csúcssebesség & 135 & 0,247 & 0,119 \\
\hline gap iránytévesztési ráta & 251 & 0,002 & 0,990 \\
overlap iránytévesztési ráta & 231,5 & 0,074 & 0,621 \\
\hline
\end{tabular}




\begin{tabular}{|l|ccc|}
\cline { 2 - 4 } \multicolumn{1}{l|}{ Antiszakkád paraméterek } & $\boldsymbol{U}$ & $\boldsymbol{r}$ & $\boldsymbol{p}$ \\
\hline gap latencia & 223 & 0,017 & 0,912 \\
overlap latencia & 209 & 0,069 & 0,651 \\
\hline gap idótartam*** & 50 & 0,662 & $<0,001$ \\
overlap idôtartam*** & 72 & 0,580 & $<0,001$ \\
\hline gap csúcssebesség & 161 & 0,176 & 0,261 \\
overlap csúcssebesség & 174 & 0,076 & 0,629 \\
\hline gap iránytévesztési ráta** & 125,5 & 0,393 & 0,010 \\
overlap iránytévesztési ráta & 157 & 0,275 & 0,071 \\
\hline
\end{tabular}

Megjegyzés: **p $\leq 0,01 ; * * * p \leq 0,001$

\section{Az életkor és a szakkádikus paraméterek összefüggése}

A proszakkád változók Kendall-féle rangkorrelációs vizsgálat 4. táblázatban bemutatott eredményei alapján megállapítható, hogy a vizsgálati alanyok életkorának növekedésével a szakkádlatencia változása az STD csoport gap feladatában gyenge, pozitív irányú és statisztikailag szignifikáns $(r=0,348 ; p=0,025)$ volt, míg a BSL csoport overlap feladatában közepes erôsségú, pozitív irányú és statisztikailag szignifikáns $(r=0,445$; $p=0,022$ ) összefüggést mutatott. A proszakkád időtartamok, csúcssebességek és iránytévesztési ráták egyik vizsgálati csoportban sem mutattak statisztikailag szignifikáns öszszefüggéseket az életkorral.

4. táblázat. Az életkor és a szakkádikus paraméterértékek összefüggésének korrelációs vizsgálata a vizsgálati csoportokban

\begin{tabular}{|l|cc|cc|}
\cline { 2 - 5 } \multicolumn{1}{c|}{} & \multicolumn{2}{c|}{ STD csoport $(\boldsymbol{N}=\mathbf{2 4})$} & \multicolumn{2}{c|}{ BSL csoport $(\boldsymbol{N}=\mathbf{2 2})$} \\
\multicolumn{1}{l|}{ Proszakkád paraméterek } & $\boldsymbol{\tau}_{b}$ & $\boldsymbol{p}$ & \multicolumn{1}{c|}{$\boldsymbol{\tau}_{\boldsymbol{b}}$} & $\boldsymbol{p}$ \\
\hline gap latencia & 0,348 & 0,025 & 0,329 & 0,091 \\
overlap latencia* & 0,225 & 0,149 & 0,445 & 0,022 \\
gap idốtartam & $-0,203$ & 0,193 & $-0,135$ & 0,487 \\
overlap idôtartam & 0,110 & 0,479 & 0,155 & 0,427 \\
gap csúcssebesség & $-0,110$ & 0,479 & $-0,019$ & 0,921 \\
overlap csúcssebesség & $-0,075$ & 0,631 & $-0,058$ & 0,766 \\
gap iránytévesztési ráta & $-0,158$ & 0,340 & $-0,291$ & 0,154 \\
overlap iránytévesztési ráta & $-0,168$ & 0,320 & 0,000 & 1,000 \\
\hline
\end{tabular}

\begin{tabular}{|l|rc|cc|}
\cline { 2 - 5 } \multicolumn{1}{c|}{} & \multicolumn{2}{c|}{ STD csoport $(\boldsymbol{N}=\mathbf{2 4})$} & \multicolumn{2}{c|}{ BSL csoport $(\boldsymbol{N}=\mathbf{2 2})$} \\
Antiszakkád paraméterek & \multicolumn{1}{c|}{$\boldsymbol{\tau}_{\boldsymbol{b}}$} & $\boldsymbol{p}$ & $\boldsymbol{\tau}_{\boldsymbol{b}}$ & $\boldsymbol{p}$ \\
\hline gap latencia** & 0,189 & 0,204 & 0,545 & 0,007 \\
overlap latencia** & $-0,070$ & 0,636 & 0,590 & 0,004 \\
gap idótartam & 0,100 & 0,501 & 0,189 & 0,351 \\
overlap idôtartam** & 0,129 & 0,384 & 0,522 & 0,010 \\
gap csúcssebesség & $-0,174$ & 0,242 & 0,011 & 0,956 \\
overlap csúcssebesség & $-0,026$ & 0,862 & 0,100 & 0,621 \\
gap iránytévesztési ráta & 0,035 & 0,827 & 0,057 & 0,782 \\
overlap iránytévesztési ráta & 0,079 & 0,623 & $-0,137$ & 0,506 \\
\hline
\end{tabular}

Megjegyzés: $\boldsymbol{\tau}_{\boldsymbol{b}}$ : Kendall's tau-b, Kendall-féle rangkorrelációs együttható; * $p \leq 0,05$; **p $\leq 0,01$ 
Az antiszakkád változók Kendall-féle rangkorrelációs vizsgálati eredménye alapján megállapítható, hogy az STD csoportban egyik szakkádparaméterre nézve sem állt fenn statisztikailag szignifikáns összefüggés a vizsgálati alanyok életkorával. A BSL csoportban a szakkádlatencia a gap feladatban $(r=0,545 ; p=0,007)$ és az overlap feladatban $(r=0,590 ; p=0,004)$ is közepes erôsségú, pozitív irányú és statisztikailag szignifikáns összefüggést mutatott. Az antiszakkád idôtartamok közül az overlap feladatban kapott, szintén ugyanilyen jellegú szignifikáns összefüggésrôl árulkodott $(r=0,522$; $p=0,010)$, míg a gap idôtartam nem mutatott szignifikáns összefüggést $(r=0,190$; $p=0,351)$. Az antiszakkád csúcssebességek és iránytévesztési ráták egyik vizsgálati csoportban sem mutattak statisztikailag szignifikáns összefüggést az életkorral.

\section{Az életkor szerepe a vizsgálati csoportok közötti szakkádparaméter-különbségekben}

Alapvetô, nem szakkádparamétereket érintô csoportkülönbséget mutattunk ki a vizsgálati alanyok életkorában, nevezetesen a BSL csoport életkora magasabb volt $(M d n$ =60,5), mint az STD csoporté $(M d n=43,0)$, és a különbség statisztikailag szignifikáns mértékú volt $(U=41 ; p<0,001 ; r=0,722)$. A két csoport eltérô férfi/nô arányára tekintettel (STD: 14/10; BSL: 16/6), a kategorikus változó diszkrét numerikus változóvá alakítását követôen (férfi $=1$, nô $=2$ ) vizsgáltuk a két csoport eltérését a nemek tekintetében. A nemi csoportátlagok alapján a két csoport között a különbség statisztikailag nem volt szignifikáns ( $U=302 ; p=0,318 ; r=0,144)$.

Tekintve, hogy a vizsgálati alanyok életkorában kimutatott lényeges csoportkülönbség befolyásolhatta a szakkádparaméterekben megfigyelt szignifikáns különbségeket, a két csoport közötti különbségek további vizsgálata során arra törekedtünk, hogy a szignifikáns mértékú szakkádparaméter-eltérésekben az életkori eltérés esetleges szerepét egyszempontos kovarianciaanalízissel (ANCOVA) tisztázzuk. A szakkádparaméterek vizsgálati csoportok közötti összehasonlító elemzéseinek összefoglaló eredményét a proszakkádok vonatkozásában a 4. ábra, az antiszakkádokra vonatkozóan az 5. ábra mutatja be.

Az életkor mint kovariáns változó kontrolljával végzett kovarianciaanalízis eredménye szerint a vizsgálati csoport típusa statisztikailag szignifikáns hatással volt a proszakkád paraméterek közül az overlap idótartam- $[F(1,43)=11,209 ; p=0,002]$ értékekre nézve. Nem igazolódott statisztikailag szignifikáns csoporttípushatás a többi proszakkád paraméterértékre nézve - gap idôtartam: $F(1,43)=0,341 ; p=0,562$; gap iránytévesztési ráta: $F(1,43)=0,533 ; p=0,469$; overlap iránytévesztési ráta: $F(1,43)=$ 0,$296 ; p=0,589$.

Az antiszakkád paraméterek közül az életkor mint kovariáns statisztikai kontrolljával kivitelezett kovarianciaanalízis eredménye szerint a vizsgálati csoport típusa szignifikáns hatással bírt a gap idôtartam $[F(1,43)=20,837 ; p<0,001]$, az overlap idôtartam $[F(1,43)=24,328 ; p<0,001]$, illetve a gap iránytévesztési ráta $[F(1,43)=6,443 ; p=$ $0,015]$ értékekre nézve. Ugyanilyen hatás nem volt kimutatható az overlap iránytévesztési ráta értékére vonatkozóan $[F(1,43)=1,473 ; p=0,232]$. 

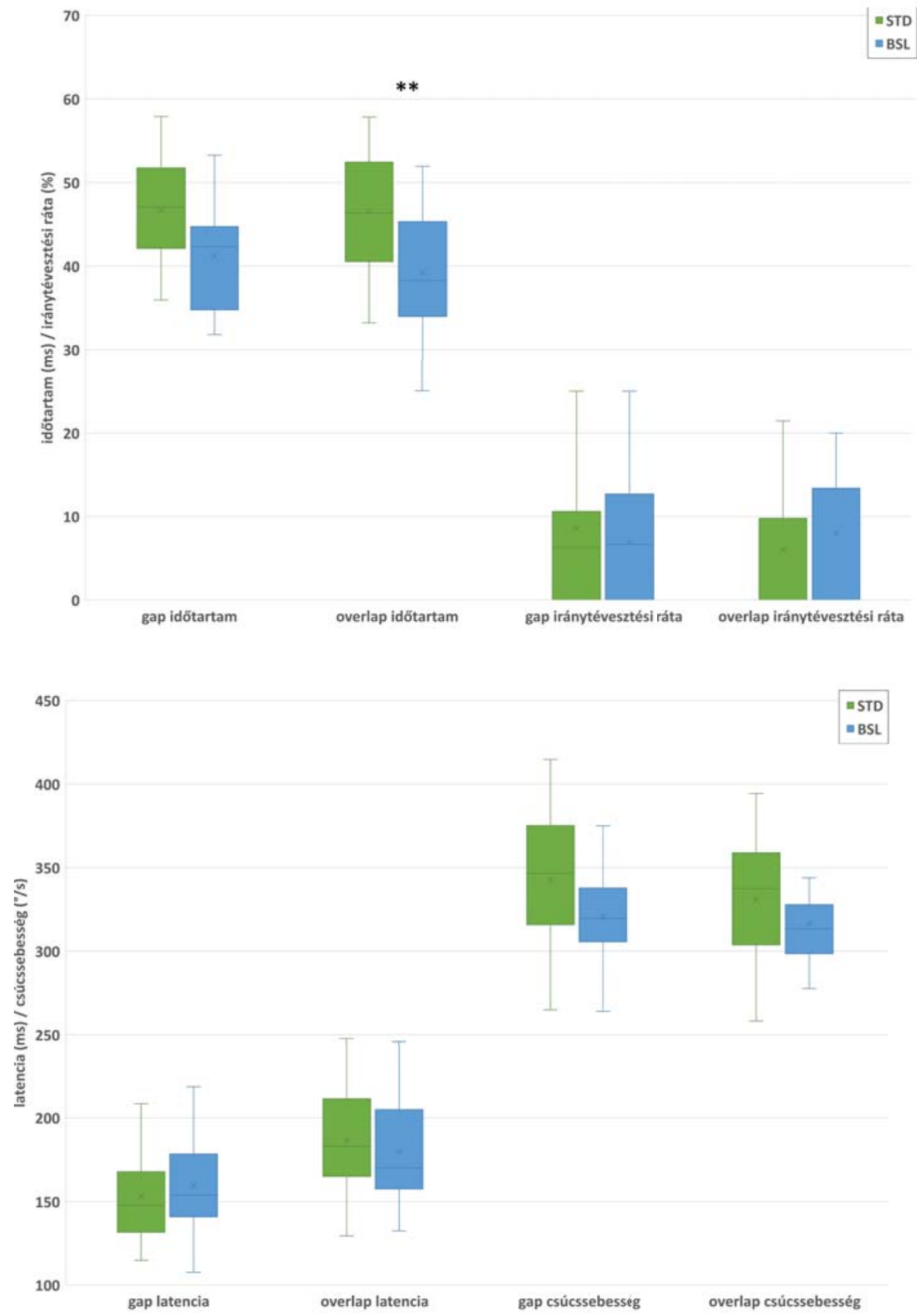

4. ábra. Proszakkád paraméterek vizsgálati csoportok közötti különbségei

Megjegyzés: balról jobbra: gap/overlap idôtartam, gap/overlap iránytévesztési ráta, gap/overlap latencia, gap/overlap csúcssebesség értékek az STD (zöld) és BSL (kék) csoportban; boxplot diagramok a változók átlag, medián, kvartilis és szórás értékeinek feltüntetésével; a csoportok közötti szignifikáns különbséget jelöltük: **p $\leq 0,01$. 

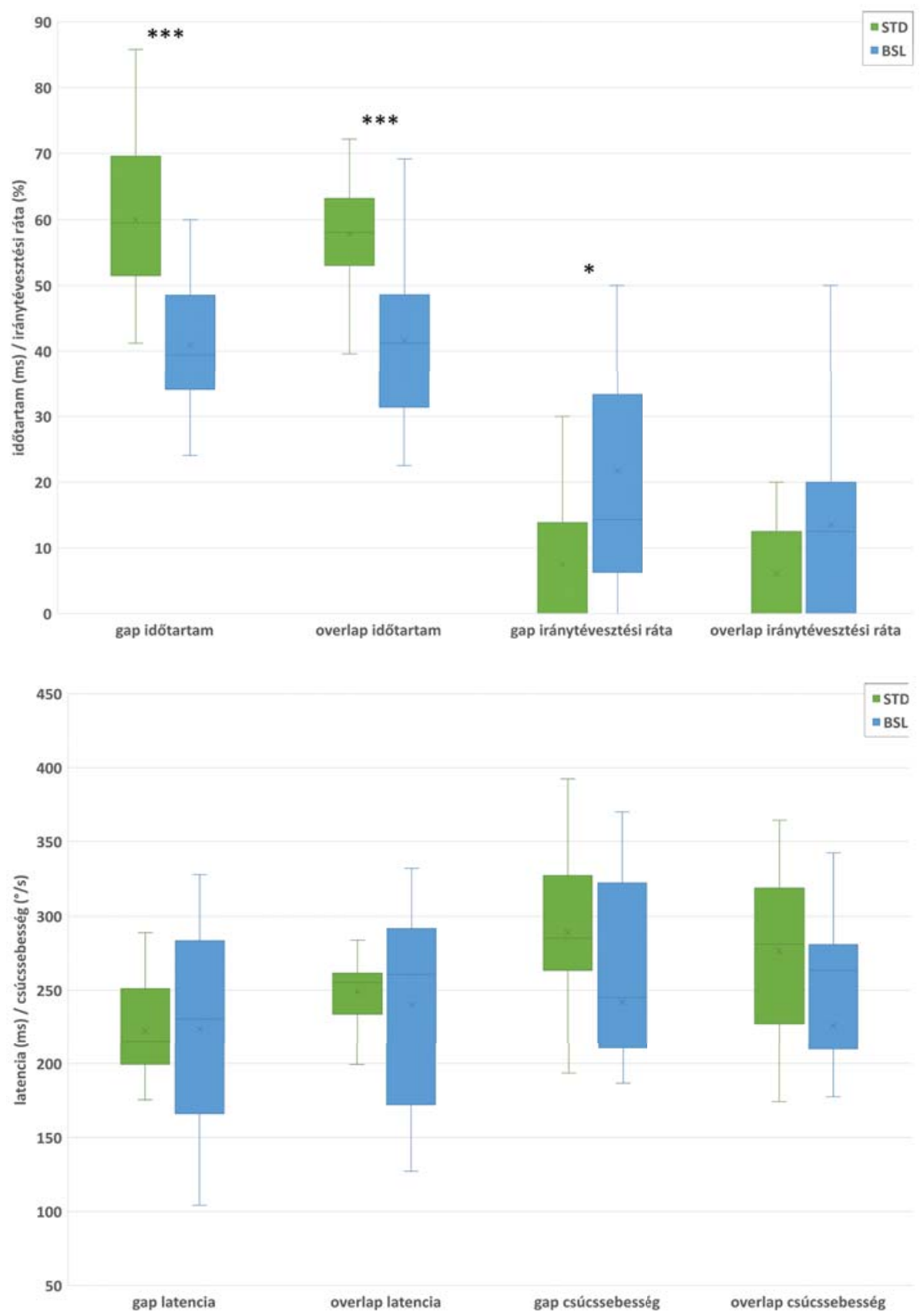

5. ábra. Antiszakkád paraméterek vizsgálati csoportok közötti különbségei

Megjegyzés: balról jobbra: gap/overlap idôtartam, gap/overlap iránytévesztési ráta, gap/overlap latencia, gap/overlap csúcssebesség értékek az STD (zöld) és BSL (kék) csoportban; boxplot diagrammok a változók átlag, medián, kvartilis és szórás értékeinek feltüntetésével; a csoportok közötti szignifikáns különbségeket jelöltük:: $* p \leq 0,05 ; * * * p \leq 0,001$. 


\section{MEGBESZÉLÉS}

Jelen vizsgálatunk, amely egy komplex, a szakkádikus szemmozgáselemzés és automatikus beszédanalízis módszereit kombináló klinikai vizsgálat részét képezi, és annak szemmozgásprotokollja elootesztelését célozta, eredményes volt a szakkádikus szemmozgások klinikai környezetben történô vizsgálatára is alkalmas vizsgálati protokoll létrehozása és egészséges alanyokon történô tesztelése szempontjából. A nemzetközi szakirodalomban található hagyományos vizsgálati protokollok jellemzőinek megfelelôen létrehozott standard (STD) tesztkörnyezetben kapott szakkádparaméter-értékek jó egyezést mutattak az egészséges kontrollszemélyek esetében korábban közölt szakkádikus latencia, idôtartam, csúcssebesség és iránytévesztési ráta vonatkozásában, mind a proszakkádikus, mind az antiszakkádikus tesztekben. Jelen vizsgálatban a nemzetközi irodalomban, egészséges alanyokon publikált szakkádparaméterek értékeivel nagymértékben megegyezó, 150 és 200 ms közötti értékeket kaptunk a latencia, 30-50 ms az időtartam, valamint 300-350 \% s a csúcssebesség tekintetében (Forbes és Klein, 1996). Vizsgálatunkban igazolni tudtuk a gap és overlap paradigma szerint kivitelezett feladatok során a gap feladatban korábban számos közlemény által dokumentált, 20-30 ms értékkel alacsonyabb latenciaértékeket (Reuter-Lorenz, Hughes és Fendrich, 1991; Fendrich, Hughes és Reuter-Lorenz, 1991), míg a szakkád idôtartam és csúcssebesség, valamint iránytévesztési ráta értékekben csupán nem számottevô különbséget detektáltunk. Ezek az overlap/gap különbségek illeszkednek a nemzetközi szakirodalomba, jó egyezést mutatnak a mások által korábban publikált eredményekkel (Saslow, 1967; Forbes és Klein, 1996).

A vizsgálatunk hagyományos STD tesztkörnyezetében kapott eredményekben ugyancsak kimutatható volt 60-70 ms antiszakkád latencianövekedés a proszakkádokéhoz viszonyítva. Saját STD csoportunkban a reflexív szakkádok 6,06-8,61\% közötti iránytévesztési rátát mutattak, ezzel igazolva önkéntes vizsgálati alanyaink többségének megfelelố teljesítményét a tesztek során; az antiszakkád iránytévesztési rátában viszont jelentôs emelkedést nem detektáltunk. Számos korábban megjelent közlemény számolt be az antiszakkád latencia és iránytévesztési ráta értékének emelkedésérôl a reflexív szakkádokéhoz viszonyítva (Amador, Schlag-Rey és Schlag, 1998; Everling és Fischer, 1998; Munoz és Everling, 2004; Edelman, Valenzuela és Barton, 2006). A latencia növekedését a vizuális ingerre adott reflexív szakkád akaratlagos gátlásához és az ellenkezô irányban indított antiszakkád generálásához szükséges idôvel magyarázzák (Coe és Munoz, 2017). A reflexív szakkád akaratlagos gátlásának vezérlésében elôforduló hibák antiszakkád iránytévesztések képében jelennek meg, melyek értéke egészséges alanyokban 5-20\% közötti átlagértéket mutat, és jelentôsen emelkedik az antiszakkád tesztben (Fischer, Gezeck és Hartnegg, 2000; Boudet és mtsai, 2005), még az ugyancsak emelkedô tendenciát mutató prediktív szakkádok (Bronstein és Kennard, 1987) kiszúrését követôen is.

Jelen vizsgálatban a kétféle vizuális tesztkörnyezetben vizsgált csoport eltéró átlagéletkora miatt elvégzett korrelációs analízis eredménye szerint a fiatalabb STD csoport életkorértéke mindössze a proszakkád gap latenciaértékével mutatott szignifikáns, közepes erôsségú, pozitív irányú összefüggést. Az idôsebb átlagéletkorú, módosított vizuális környezetben történt ingerbemutatás során (BSL csoport) az életkor változója 
ugyanilyen összefüggésben volt az antiszakkád gap latencia, a proszakkád és antiszakkád overlap latencia, valamint az overlap idôtartam értékével. Ezek az eredmények szinkronban állnak a mások által korábban publikált megfigyeléssel, amely szerint a reflexív szakkádok reakcióideje enyhe emelkedést mutat az életkor elôrehaladtával (Munoz, Broughton és Goldring, 1998), ami egyformán igaznak bizonyult a reflexív és az antiszakkádok tekintetében is (Hopf és mtsai, 2018; Eenshuistra, Ridderinkhof és Van der Molen, 2004). A szakkád csúcssebességekre nézve nem találtunk szignifikáns összefüggést az életkorral, és ezek az eredmények egybecsengenek a nemzetközi irodalomban található adatokkal (Warabi, Kase és Kato, 1984; Fischer, Biscaldi és Gezeck, 1997; Munoz, Broughton és Goldring, 1998; Eenshuistra, Ridderinkhof és Van der Molen, 2004; Peltsch és mtsai, 2011; Hopf és mtsai, 2018).

A vizsgálatban alkalmazott kétféle vizuális tesztkörnyezetben kapott proszakkád és antiszakkád paraméterek egymással történô összehasonlítása alapján szignifikáns különbségeket detektáltunk a proszakkádok és antiszakkádok hosszát, illetve az antiszakkád iránytévesztési rátákat illetôen. Továbbá a vizsgálatban alkalmazott kétféle vizuális tesztkörnyezetben a vizsgálati csoportok között szignifikáns különbséget mutató szakkádparaméterek összehasonlítását az életkor statisztikai kontrollja mellett megismételve, változatlanul szignifikáns különbséget találtunk a proszakkád overlap idôtartam, az antiszakkád gap és overlap idôtartam, valamint az antiszakkád iránytévesztési ráta vonatkozásában. Ez az eredmény arra enged következtetni, hogy a két vizsgálati csoport által produkált szignifikáns különbségek hátterében nem a csoportok eltéró életkori sajátossága, hanem feltételezhetôen a két eltérô vizuális tesztkörnyezet hatása - nevezetesen, az alkalmazott ingerek színességének vagy a BSL háttérképnek tulajdonítható hatás - játszhat szerepet. Ez a hatás különösen markánsan mutatkozott meg az antiszakkád időtartamok jelentôs, 17-20 ms csökkenésében és az antiszakkád iránytévesztési hibaráta kimutatott 7-12\%-os emelkedésében. A koherensnek és statisztikailag megbízhatónak tekinthetô ezen eredményeink limitációjaként szeretnénk feltüntetni, hogy bár a normalitásvizsgálat nem teljesült minden vizsgált változó esetében, az életkor statisztikai kontrollja mellett kivitelezett elemzéseinkhez egyszempontos kovarianciaanalízist (ANCOVA) alkalmaztunk. Ennek hátterében az ANCOVA próba nem normalitásra mutatott ismert robusztussága, illetve a kapott eredmények magasfokú megbízhatósága állt (alacsony p-értékek).

Az általunk alkalmazott kétféle vizuális tesztkörnyezet a háttérképben és a megjelenített vizuális ingerek színes/szürkeárnyalatos mivoltában eltérô volt. Korábbi vizsgálatokban kimutatásra került, hogy a szakkádparaméterek latenciaértékében szignifikáns növekedést eredményez az alkalmazott ingerek színessége (Satgunam és Fogt, 2005). A saját kétféle vizuális tesztkörnyezetünkben a szakkádlatenciákban elhanyagolható, nem szignifikáns mértékú eltéréseket találtunk a végrehajtott vizsgálatainkban, ezért a megfigyelt többi szakkádikus különbségért feltételezhetốn nem az eltérô színú ingerek voltak felelôsek, hanem a különbözô vizuális tesztkörnyezeti háttér.

A szakkádikus szemmozgásvizsgálatokban alkalmazott, térbeli disztraktor paradigma alapján kivitelezett vizsgálatokban a proximális és távoli disztraktorok szakkádparaméterekre gyakorolt hatásával kapcsolatban számos korábbi közlemény jelent meg (Van der Stigchel, Mulckhuyse és Theeuwes, 2009; Findlay és Blythe, 2009; McSorley, McCloy és Lyne, 2012; Buonocore és McIntosh, 2012; Heeman, Van de 
Stigchel és Theeuwes, 2017). Ezek a térbeli disztraktorok a szakkádikus ingerrel egyidejûleg, csak rövid ideig megjelenített, figyelemelterelô célú extra ingereket jelentik, amelyek a tesztkörnyezet hátterétôl teljesen függetlenül fejtik ki hatásukat, és általában a szakkádok latenciáját és pontosságát változtatják meg. Azonban egy, az itt bemutatott vizsgálatunkhoz hasonló, a vizsgálati tesztkörnyezet hátterének a szakkádikus paraméterek értékeire gyakorolt hatását részletesen vizsgáló tanulmányban (White, Stritzke és Gegenfurtner, 2008) bizonyítást nyert, hogy az egyszínú, sötét háttéren megjelenített fehér szakkádikus ingereket alkalmazó hagyományos tesztkörnyezethez képest, a strukturált grafikát vagy fơleg természetes külsô színtereket ábrázoló hátteret alkalmazó tesztkörnyezetben a szakkád latenciaértékek szignifikánsan rövidülnek. Ez a feltételezett hatás jelen vizsgálatunkban nem jelentkezett, tekintve, hogy az összes vizsgált szakkádparaméter közül éppen a latenciák mutatták a legkisebb, elhanyagolható nagyságú és nem szignifikáns különbséget a kétféle vizuális tesztkörnyezetben. White és munkatársai (2008) az általuk megfigyelt latenciarövidülés mechanizmusát abban látták, hogy a strukturált háttér az általa preaktivált agyi szakkádikus hálózat segítségével biztosítja a természetes környezetben nehezebben felismerhetô, potenciálisan kritikus ingerekre adott gyors válaszreakciót. A saját vizsgálatunkban kimutatott szakkádidôtartam és iránytévesztési ráta különbségeinek lehetséges magyarázata feltételezhetôen másban keresendô: a Boston Sütilopás háttérkép látványa, illetve egyes részletei által feltételezhetô, hogy növelheti a vizsgálat során fellépô kognitív terhelést, és ez magasabb szakkádikus hibarátához és csökkent szakkádhosszhoz vezethet.

A szakkádparaméterek érzékeny méréséhez az elterjedten használt, álltámaszt alkalmazó és fejmozgást kizáró, erósen mesterséges laboratóriumi körülményeket jelentô módszertan helyett az általunk használt kisméretú, hordozható Tobii Pro X3-120 berendezésre alapuló kétféle vizuális környezetet biztosító vizsgálati protokoll a mindennapi klinikai gyakorlatban is egyszerúen, gyorsan és könnyen alkalmazható, a páciensek és a vizsgálószemélyzet szempontjából is természetesebb és barátságosabb vizsgálórendszert jelenthet, ami nagyban hozzájárulhat a módszer szélesebb körben történô klinikai alkalmazásához és elterjedéséhez.

\section{KÖSZÖNETNYILVÁNÍTÁS}

A vizsgálatokhoz használt szemmozgásvizsgáló berendezések és szoftver, valamint a közremúködôk finanszírozása részben a „Telemedicina alapú ellátási formák fenntartható megvalósítását támogató keretrendszer kialakítása és tesztelése” címú GINOP-2.2.1-15-2017-00073 projekt keretében történt. 


\section{IRODALOM}

Amador, N., Schlag-Rey, M., \& Schlag, J. (1998). Primate antisaccades. I. Behavioral characteristics. Journal of Neurophysiology, 80(4), 1775-1786.

Antoniades, C., Ettinger, U., Gaymard, B., Gilchrist, I., Kristjánsson, A., Kennard, C., John Leigh, R., Noorani, I., Pouget, P., Smyrnis, N., Tarnowski, A., Zee, D. S., \& Carpenter, R. H. (2013). An internationally standardised antisaccade protocol. Vision Research, 84, 1-5.

Bahill, A. T., Clark, M. R., \& Stark, L. (1975). The main sequence: A tool for studying human eye movements. Mathematical Biosciences, 24(3-4), 191.

Boudet, C., Bocca, M. L., Chabot, B., Delamillieure, P., Brazo, P., Denise, P., \& Dollfus, S. (2005). Are eye movement abnormalities indicators of genetic vulnerability to schizophrenia? European psychiatry: the journal of the Association of European Psychiatrists, 20(4), 339-345.

Bronstein, A. M., \& Kennard, C. (1987). Predictive eye saccades are different from visually triggered saccades. Vision Research, 27(4), 517-520.

Buonocore, A., \& McIntosh, R. D. (2012). Modulation of saccadic inhibition by distractor size and location. Vision Research, 69, 32-41.

Coe, B. C., \& Munoz, D. P. (2017). Mechanisms of saccade suppression revealed in the antisaccade task. Philosophical transactions of the Royal Society of London. Series B, Biological Sciences, 372(1718), 20160192.

Edelman, J. A., Valenzuela, N., \& Barton, J. J. (2006). Antisaccade velocity, but not latency, results from a lack of saccade visual guidance. Vision Research, 46(8-9), 1411-1421.

Eenshuistra, R. M., Ridderinkhof, K. R., \& Van der Molen, M. W. (2004). Age-related changes in antisaccade task performance: inhibitory control or working-memory engagement? Brain and Cognition, 56(2), 177-188.

Everling, S., \& Fischer, B. (1998) The antisaccade: a review of basic research and clinical studies. Neuropsychologia, 36(9), 885-899.

Fendrich, R., Hughes, H. C., \& Reuter-Lorenz, P. A. (1991). Fixation-point offsets reduce the latency of saccades to acoustic targets. Perception \& Psychophysics, 50(4), 383-387.

Findlay, J. M., \& Blythe, H. I. (2009). Saccade target selection: Do distractors affect saccade accuracy? Vision Research, 49(10), 1267-1274.

Fischer, B., Biscaldi, M., \& Gezeck, S. (1997). On the development of voluntary and reflexive components in human saccade generation. Brain Research, 754(1-2), 285-297.

Fischer, B., Gezeck, S., \& Hartnegg, K. (2000). On the production and correction of involuntary prosaccades in a gap antisaccade task. Vision Research, 40(16), 2211-2217.

Fischer, B., \& Weber, H. (1992). Characteristics of ,anti” saccades in man. Experimental Brain Research, 89(2), 415-424.

Fischer, B., \& Weber, H. (1997). Effects of stimulus conditions on the performance of antisaccades in man. Experimental Brain Research, 116(2), 191-200.

Forbes, K., \& Klein, R. M. (1996). The magnitude of the fixation offset effect with endogenously and exogenously controlled saccades. Journal of Cognitive Neuroscience, 8(4), 344-352.

Forbes-McKay, K. E., \& Venneri, A. (2005). Detecting subtle spontaneous language decline in early Alzheimer's disease with a picture description task. Neurological Sciences, 26(4), 243254.

Giles, E., Patterson, K., Hodges, J. R. (1996). Performance on the Boston Cookie Theft picture description task in patients with early dementia of the Alzheimer's type: missing information. Aphasiology, 10(4), 395-408.

Goodglass, H., \& Kaplan, E. (1983). The assessment of aphasia and related disorders. 2nd Ed. Philadelphia, PA: Lea and Febiger. 
Gosztolya, G., Vincze, V., Tóth, L., Pákáski, M., Kálmán, J., \& Hoffmann, I. (2019). Identifying mild cognitive impairment and mild Alzheimer's disease based on spontaneous speech using ASR and linguistic features. Computer Speech \& Language, 53, 181-197.

Hallett, P. (1978). Primary and secondary saccades to goals defined by instructions. Vision Research, 18(10), 1279-1296.

Heeman, J., Van der Stigchel, S., \& Theeuwes, J. (2017). The influence of distractors on express saccades. Journal of Vision, 17(1), 35.

Hopf, S., Liesenfeld, M., Schmidtmann, I., Ashayer, S., \& Pitz, S. (2018). Age dependent normative data of vertical and horizontal reflexive saccades. PloS One, 13(9), e0204008.

Hutton, S. B., \& Ettinger, U. (2006). The antisaccade task as a research tool in psychopathology: A critical review. Psychophysiology, 43, 302-313.

Javaid, F. Z., Brenton, J., Guo, L., \& Cordeiro, M. F. (2016). Visual and ocular manifestations of Alzheimer's disease and their use as biomarkers for diagnosis and progression. Frontiers in Neurology, 7, 55.

Klein, C. H., Raschke, A., \& Brandenbusch, A. (2003). Development of pro- and antisaccades in children with attention-deficit hyperactivity disorder (ADHD) and healthy controls. Psychophysiology, 40, 17-28.

Komogortsev, O. V., Gobert, D. V., Jayarathna, S., Koh, D. H., \& Gowda, S. (2010). Standardization of automated analyses of oculomotor fixation and saccadic behaviors. IEEE Transactions on Bio-medical Engineering, 57(11), 10.1109/TBME.2010.2057429.

Leigh, R. J., \& Zee, D. S. (2006). The neurology of eye movements. New York: Oxford University Press.

Liu, B., Zhao, Q., Ren, Y., Wang, Q., \& Zheng, X. (2018). An elaborate algorithm for automatic processing of eye movement data and identifying fixations in eye-tracking experiments. $A d$ vances in Mechanical Engineering, 10(5), 168781401877367.

McSorley, E., McCloy, R., \& Lyne, C. (2012). The spatial impact of visual distractors on saccade latency. Vision Research, 60(1), 61-72.

Munoz, D. P., Broughton, J., \& Goldring, J. (1998). Age-related performance of human subjects on saccadic eye movement tasks. Experimental Brain Research, 121, 391-400.

Munoz, D. P., \& Everling, S. (2004). Look away: the anti-saccade task and the voluntary control of eye movement. Nature Reviews. Neuroscience, 5(3), 218-228.

Peltsch, A., Hemraj, A., Garcia, A., \& Munoz, D. P. (2014). Saccade deficits in amnestic mild cognitive impairment resemble mild Alzheimer's disease. The European Journal of Neuroscience, 39(11), 2000-2013.

Peltsch, A., Hemraj, A., Garcia, A., \& Munoz, D. P. (2011). Age-related trends in saccade characteristics among the elderly. Neurobiology of Aging, 32, 669-679.

Reuter-Lorenz, P. A., Hughes, H. C., \& Fendrich, R. (1991). The reduction of saccadic latency by prior offset of the fixation point: an analysis of the gap effect. Perception \& Psychophysics, 49(2), 167-175.

Salvucci, D. D., \& Goldberg, J. H. (2000). Identifying fixations and saccades in eye-tracking protocols. Proceedings of the Eye Tracking Research and Applications Symposium (ETRA 2000), 71-78.

Saslow, M. G. (1967). Effects of components of displacement-step stimuli upon latency for saccadic eye movement. Journal of the Optical Society of America, 57(8), 1024-1029.

Satgunam, P., \& Fogt, N. (2005). Saccadic latencies for achromatic and chromatic targets. Vision Research, 45(27), 3356-3364.

Van der Stigchel, S., Mulckhuyse, M., \& Theeuwes, J. (2009). Eye cannot see it: the interference of subliminal distractors on saccade metrics. Vision Research, 49(16), 2104-2109.

Warabi, T., Kase, M., \& Kato, T. (1984). Effect of aging on the accuracy of visually guided saccadic eye movement. Annals of Neurology, 16(4), 449-454. 
Warr, L., \& Walker, Z. (2012). Identification of biomarkers in Lewy-body disorders. The quarterly journal of nuclear medicine and molecular imaging, 56(1), 39-54.

White, B. J., Stritzke, M., \& Gegenfurtner, K. R. (2008). Saccadic facilitation in natural backgrounds. Current Biology: CB, 18(2), 124-128.

Yang, Q., Wang, T., Su, N., Xiao, S., \& Kapoula, Z. (2013). Specific saccade deficits in patients with Alzheimer's disease at mild to moderate stage and in patients with amnestic mild cognitive impairment. Age (Dordrecht, Netherlands), 35(4), 1287-1298.

\section{EYE MOVEMENT ANALYSIS IN A TRADITIONAL AND A NOVEL TEST ENVIRONMENT: DISTRACTOR EFFECT ON SACCADIC PARAMETERS BY THE VISUAL BACKGROUND}

\section{SOMOSKEÖY, SZABOLCS - KOVÁCS, ILDIKÓ - MEZEI, MÁRTON - HOFFMANN, ILDIKÓ - TÓTH, LÁSZLÓ - GOSZTOLYA, GÁBOR - IMRE, NÓRA - BALOGH, RÉKA - PÁKÁSKI, MAGDOLNA - KÁLMÁN, JÁNOS - FEHÉR, ANDRÁS}

Background and aims: The use of saccadic parameters as specific biomarkers in the diagnosis of degenerative neuropsychiatric disorders is still problematic. The aim of the current study was to 1) establish a protocol for saccadic eye movement measurements that is concordant with international clinical investigations; 2) compare saccadic parameters of healthy subjects with internationally published data, and 3) integrate the picture from Boston Cookie Theft test into the visual test environment and evaluate its distractor effects on saccadic parameters.

Methods: Healthy volunteers were assessed with Tobii Pro X3-120 eye tracker in two distinct visual settings, but otherwise identical test environment evaluating prosaccades and antisaccades in gap and overlap conditions. One group was assessed in a visual test environment based on a traditional uniform grey background with black stimuli (STD test group), while the visual test environment of the other group contained the Cookie Theft picture of the Boston Diagnostic Aphasia Examination with green and red stimuli (BSL group).

Results: Prosaccade and antisaccade latencies were significantly longer in the overlap condition both in the $B S L$ and STD groups. After controlling for age, the STD and BSL group did not differ in terms of prosaccade latency, antisaccade latency or peak velocity; only saccade durations were shorter in the BSL group. Saccadic direction error rate in the prosaccade task was identical in both groups, while the antisaccade gap duration, overlap duration and gap direction error rates showed significant group differences.

The present, newly developed protocol conforms to international standards, and may be useful for multimodal clinical studies assessing healthy subjects and people suffering from dementia, combined with traditional neuropsychological tasks and the speech recognition task recently developed by our research group.

Keywords: saccadic eye movement, reflexive saccade, anti-saccade, Boston Cookie Theft picture, distractor 